\title{
LANGUAGE PROBLEMS IN APPLIED LINGUISTICS: LIMITING THE SCOPE
}

\author{
A. Effendi Kadarisman \\ (effendi.kadarisman@gmail.com) \\ Universitas Negeri Malang \\ Jalan Semarang 5 Malang 65145, Indonesia
}

\begin{abstract}
This article critically discusses the paradigmatic shift in applied linguistics, resulting in a claim that countless real-world language problems fall within its scope, but in reality they weaken the discipline and make it lack a focus. Then it takes a closer look at the nature of these language problems, and picks out, for analysis, real examples of writing problems in ELT in Indonesian context. It further argues that, by focusing primarily on problems in ELT and SLA, applied linguistics reaffirms its well-defined position and underscores its significant contributions to both disciplines. Finally, it concludes the discussion by adding some notes on the question of autonomy in both applied linguistics and in ELT in Indonesia.
\end{abstract}

Keywords: applied linguistics, language problems, paradigmatic shift, ELT in Indonesia, question of autonomy

In applied linguistics (AL) today the term 'language problem' has become a key concept. Davies (2004) argues that the discipline is primarily devoted to seeking "a practical answer to a language problem" (p. 19). Along this line of argument, McCarthy (2001, p. 1), citing Brumfit (1991, p. 46), states that applied linguistics tries to offer solutions to "real-world problems in which language is a central issue"; and hence it is appropriately called "a problem-driven discipline" (p. 3). Similarly, Cook and Wei (2009, p. 3) use the term "realworld language problems", and note that the International Association of Applied Linguistics specifies the term as "practical problems of language and communication" (p. 1). Likewise, Davies and Elder (2004) use a similar term "social problems involving language" (p. 1). 
A problem arises when applied linguistics tries to encompass all kinds of real-world language problems. This huge and unlimited scope of AL may suggest, on the one hand, that AL has become a very powerful discipline, taking up everything concerning language and any of its related problems. On the other hand, it implies that AL lacks a focus; for when it deals with everything, it eventually deals with nothing (Hult, 2008, p. 12).

'Language problems' in AL thus present themselves as puzzling phenomena, which deserve serious attention and need further investigation. Accordingly, the present article raises five inter-related questions. Why do language problems in AL seem to be limitless and endless? What is the nature of language problems in AL? What does ELT in Indonesian context look like, particularly in dealing with writing problems? What is the actual role of AL vis-à-vis ELT and SLA? What is the nature of AL relationship with theoretical linguistics? Answers to these five questions are the major concerns of this article; and they are presented in order.

\section{PARADIGMATIC SHIFT: FROM LINGUISTICS APPLIED TO APPLIED LINGUISTICS}

The seemingly endless 'language problems' making up the boundless scope of AL are probably the effect of paradigmatic shift in the discipline. Applied linguists today (see, e.g., Davies and Elder, 2004; McCarthy, 2001; Widdowson, 1984) claim that AL is not simply the application of linguistic theories, principles, methods, or techniques for the purpose of solving language problems at hand. On the contrary, AL is now an autonomous and independent discipline (Rajagopalan, 2004). Although the word 'linguistics' stands, syntactically, as the head being modified by 'applied' in the given name 'applied linguistics', AL is no longer under the shadow of linguistics, let alone an offshoot of it. In fact, (theoretical or context-free) linguistics is only one of the numerous disciplines (such as sociolinguistics, pragmatics, discourse analysis, psychology, sociology, education, and many more) to which AL relates in a collaborative, not a dependent manner (Cook and Wei, 2009; Spolsky, 2008).

Along this line of argument, Davies and Elder (2004), following Widdowson (2000), have distinguished between Linguistics Applied (LA) and Applied Linguistics (AL). The former, also termed 'applications of linguistics', refers to "the assumption that the [language] problem can be reformulated by the direct and unilateral application of concepts and terms deriving from lin- 
guistic enquiry itself" (p. 9). In my opinion, one best example of LA can be seen in the direct application of Bloomfieldian linguistic principles in the field of FL teaching, producing the well-known Audiolingual Method (ALM), summarized in Table 1. As shown in this table, the relationship between the linguistic principles and their application in the ALM is quite straightforward. All the three principles and their applications are self-explanatory and need no further explanation.

Table 1. Bloomfieldian Principles and their Application in the ALM

\begin{tabular}{ll}
\hline Linguistic Principles & Application in the ALM \\
\hline Language is primarily speech. & Teach speech before writing. \\
\hline Language is a set of habits. & Do drilling as the best way of forming FL habits. \\
\hline Every language is different. & $\begin{array}{l}\text { Do contrastive analysis as the basis for material } \\
\text { development and predicting errors. }\end{array}$ \\
\hline
\end{tabular}

The first scholarly attempt to build the ALM began with the work of Fries (1945) and reached its peak in the work of Lado (1964). Lado's book Language Teaching bears the sub-title A Scientific Approach, which implicitly refers to the claim that linguistics is a science in the sense that physics or chemistry is a science (Bloomfield, 1933, p. 33). One important characteristic of a science is providing "high precision" in describing its objects of investigation. Thus 'scientific approach' means linguistics-based approach and hence provides 'guidance of high precision' as how to conduct FL teaching.

By and large, Lado's Language Teaching can be seen as the 'holy bible' for the ALM. It succinctly outlines linguistic and psychological principles of language learning and language teaching (see chapters 4 and 5). It defines 'learning a second language' as "acquiring the ability to use its structure within a general vocabulary under essentially the conditions of normal communication among native speakers at conversational speed" (p. 38). Overall, the book is a complete manual of FL teaching geared toward helping the learners to achieve structural and lexical mastery as the basis for communicative ability.

In other words, according to the ALM, mastering a second language begins with mastering language form and moves toward proficiency in language function. The well-known instructional materials faithfully based on the ALM are English 900 series, which had world-wide circulation during the 1970s. In Indonesia, during the 1970s through the early 1980s Student Book and its Sup- 
plementary Reader (volumes 1, 2, 3, respectively) for senior high schools were also ALM-based materials. In sum, despite its failure owing to the wrong linguistic and psychological assumptions (Brown, 2001, pp. 23-24), the ALM is probably one best example of LA (Linguistics Applied) in the field of FL teaching. ${ }^{1}$

By contrast, while LA can be seen as direct application of linguistic principles to solve a given problem, AL requires "intervention [as] a matter of mediation"; [it] has to relate and reconcile different representations of reality, including that of linguistics without excluding others" (Davies and Elder, 2004, p. 9). An excellent example is given by Widdowson (1984, p. 14) in his critique of Chomsky's (1957, p. 87) famous examples:

(1) Flying planes can be dangerous.

This sentence is syntactically ambiguous, interpretable in two different ways:

a. It can be dangerous to fly planes.

b. Planes which fly can be dangerous.

While paraphrase (2.b) is syntactically acceptable, it is, according to Widdowson, pragmatically vacuous. What a plane does is of course fly; and why should it be dangerous? He further goes on providing a pragmatically acceptable interpretation.
a. Planes can be dangerous when they fly.
b. Planes can be dangerous when flying.
c. Planes can be dangerous flying.
d. Flying planes can be dangerous.

The series of paraphrases in (3) make up a brilliant argument. While sentence (1) by Chomsky is syntactically ambiguous but somewhat meaningless pragmatically, paraphrase (3.d) by Widdowson, which has gone through a long derivation from (3.a), is not only syntactically ambiguous but also pragmatically

\footnotetext{
1 Another example of LA in the sense of 'applications of linguistics', particularly in the field of English Language Teaching (ELT), is Allen's (1964) Readings in Applied English Linguistics. This book is a collection of 62 articles, showing the practical use of linguistic knowledgederived, then, mostly from the well-established Bloomfieldian school and partly from the newly emerging Chomskyan school-in teaching English, both as a national language in the United States and as a foreign language, in either the United States or other countries.
} 
meaningful. This is a great example of providing 'a different representation of reality'.

Widdowson (1984, pp. 9-10) further notes the major difference between linguistic analysis and native speaker's intuition. In linguistic analysis, accurate description is the ultimate goal, allowing 'no tolerance for vague notion, imprecision, and ambiguity'. Conversely, 'communicative behavior' which represents native speakers' communicative competence 'is [often] vague, imprecise, and ambiguous'. This can be seen through the difference between 'syntactic ambiguity' and 'pragmatic indeterminacy'. Syntactic ambiguity can always be resolved by drawing different tree structures and providing paraphrases, revealing that a given syntactic construction (in natural language data) may be ambiguous in two or three different ways - as illustrated by Flying planes can be dangerous in (1).

On the other hand, pragmatic indeterminacy, as the term suggests, may have countless interpretations depending on the given context. Consider the following utterances by A and B in dialogue (4).

$$
\begin{aligned}
& \text { A: Will you? } \\
& \text { B: Of course. }
\end{aligned}
$$

The question and answer in elliptical forms here imply that the 'speaker meanings' are determined by a previous 'text', that is, a previous verbal communication by both interlocutors A and B. Now the reader can imagine unlimited numbers of previous conversations which allow the generation of both utterances in (4) and at the same time determine their communicative intents.

For the sake of economy, Table 2 gives a summary contrasting between LA and AL, or between the old and new paradigms pertaining to applied linguistics. As shown in Table 2, LA, which belongs to the old paradigm, is a dependent discipline subsumed under theoretical linguistics, whose primary task is applying linguistic principles to solve language problems, particularly those in the area of FL teaching and learning. In contrast, AL, which claims to have set up a new paradigm, relates to linguistics in a collaborative manner; and hence it is an autonomous problem-driven discipline. It is concerned with realworld language problems and tries to offer the best possible solutions by relating them, either directly or indirectly, not only to linguistics but also to other relevant disciplines. Briefly, the paradigmatic shift from LA to AL is not only a liberating move from affiliation to autonomy, but also an exploding coverage 
of the subject matter: from the limited problems in the area of FL teaching and learning to a boundless scope covering practically all kinds of language problems.

Table 2. Comparing Linguistics Applied with Applied Linguistics

\begin{tabular}{lll}
\hline \multirow{2}{*}{ Parameter } & APPLIED LINGUISTICS & \\
\cline { 2 - 3 } $\begin{array}{l}\text { relation to theoretical } \\
\text { linguistics }\end{array}$ & Old Paradigm (LA) & New Paradigm (AL) \\
\hline status as a discipline & dependent & partnership or collaborative \\
\hline \multirow{2}{*}{ name and method } & $\begin{array}{l}\text { Linguistics Applied = applying } \\
\text { linguistic principles to solve }\end{array}$ & $\begin{array}{l}\text { Applied Linguistics }= \\
\text { identifying problems and } \\
\text { finding solutions in a sys- } \\
\text { tematic way (problem-driven } \\
\text { discipline) }\end{array}$ \\
\hline \multirow{2}{*}{ scope of subject matter } & $\begin{array}{l}\text { limited to / focused on FL } \\
\text { teaching and learning }\end{array}$ & $\begin{array}{l}\text { any real-world language- } \\
\text { related problem }\end{array}$ \\
\hline
\end{tabular}

A cautionary note is necessary here. The term 'LA' (as an old paradigm) is given by present-day applied linguists to justify that AL is an independent discipline, going far beyond the applications of linguistics and hence no longer under its domination. Former scholars such as Fries (1945) and Lado (1964), however, never saw themselves that way, but rather conceived themselves and were admitted by other contemporary and forthcoming scholars as pioneers in the field of FL teaching. By analogy, one often considers oneself 'a good guy' by pointing a finger at (frequently dead) enemies and calls them 'bad guys'. The derogatory term LA is probably needed to promote the position of AL and makes it look promising academically.

\section{A CLOSER LOOK AT LANGUAGE PROBLEMS IN APPLIED LIN- GUISTICS}

This section provides an answer to the second question: What is the nature of language problems in AL? Before answering this question, it is necessary to take a look at the 'lists of possible problems' making up the scope of AL, as proposed, for example, by Cook (2003), Davies and Elder (2004), and McCarthy (2001). Cook (2003, pp. 7-8) identifies three headings as follows: (1) language and education; (2) language, work, and law; and (3) language, infor- 
mation, and effect. The first heading includes (a) first-language education; (b) second- and foreign-language education; (c) clinical linguistics; and (d) language testing. The second heading includes (a) workplace communication; (b) language planning; and (c) forensic linguistics. The third heading includes (a) literary stylistics; (b) critical discourse analysis; (c) translation and interpretation; (d) information design; and (e) lexicography.

Davies and Elder $(2004$, p. 1) present the language problems in a series of questions. They are problems in the areas of (a) language teaching; (b) speech pathology; (c) translation and interpretation; (d) language testing; (e) bilingual program; (f) literacy; (g) discourse analysis; (h) medium of instruction; (i) second language acquisition; and (j) legal language.

McCarthy (2001, p. 1) gives a list of 14 problems - in the following areas: (a) speech therapy; (b) foreign language teaching; (c) legal language; (d) advertising; (e) report writing; (f) historic naming; (g) language testing; (h) literary studies; (i) lexicography; (j) machine translation; (k) language planning; (l) international navigation; (m) primate/animal communication; and (n) medical sociology. Then McCarthy adds "the list could continue, and ... is quite likely to grow even bigger over the years" (p. 2).

Under critical examination, the three long lists of language problems above teach us three important lessons. First, as noted earlier, AL has become so ambitious that it tries to claim that every language-related problem is within the confines of its subject matter. This has been criticized by Cook and Wei (2009), saying, "definitions of applied linguistics now are more like lists of the areas that make it up" (p. 1). In other words, AL has no focus of scholarly interest, making "the applied linguist a Jack of all trades", one who "knows a little about many areas" (p. 2). If so, then AL seems to have failed to become a field of specialization.

Secondly, it is doubtful that people encountering all of those language problems listed above will come and consult with applied linguists for the best possible solutions. Many areas listed above are academic disciplines of their own; discourse analysis, critical discourse analysis, lexicography, and forensic linguistics are sub-fields of linguistics. And language planning is much closer to sociolinguistics than to AL. Under the umbrella of 'language education', foreign language teaching, language testing, and second language acquisition are autonomous disciplines; and so is translation. Advertising probably needs more insight from stylistics than from AL; and stylistics is part of literary studies. Briefly, each of these well-established disciplines has produced scholars of 
its own, whose expertise is much needed when problems arise in the discipline. A Jack of all trades can never compete against an expert.

Third and finally, the three lists have two things in common: foreign language teaching (FLT) and second language acquisition (SLA) ${ }^{2}$. In fact, they constitute the home base for AL. Despite its claim for such a broad coverage in subject matter, it is these two areas that have been in close contact with AL. Cook and Wei (2009) observe, "The International Association of Applied Linguistics Congress in 2008 had nine papers on first language acquisition compared with 161 on second language acquisition and 138 on foreign language teaching" (p. 1). Clearly, SLA and FLT made up the backbone for the congress. The close connection between FLT and AL is further confirmed by Hult (2008), "The predominant notion of applied linguistics is that it serves the needs of language teaching, particularly ELT" (p. 14).

In brief, the nature of countless language problems in AL is that they are conceived rather imaginary than real. The real problems AL has been dealing with in earnest are problems in FLT and SLA. In is in these two areas that AL has been most successful (Cook \& Wei, 2009, p. 3). The following section will take a closer examination of EFL teaching and learning in Indonesia, and pick out examples of naturally occurring classroom problems.

\section{ELT IN INDONESIAN CONTEXT: A CLOSER LOOK AT WRITING PROBLEMS}

The term 'problem' is in itself problematic. As Cook and Wei (2009) puts it, "in one sense it means a research question posed in a particular discipline; in another sense it is something that has gone wrong which can be solved" (p. 2). A more careful scrutiny should reveal that, between 'something wrong' and 'research question', there are other possible interpretations of 'problem'. Thus 'problem' has multifarious meanings, ranging from the most negative to the near-neutral. I would propose that the semantic range includes (a) error; (b)

\footnotetext{
2 The term "second language" or L2 in SLA literature refers to "any language learned after learning the L1, regardless of whether it is the second, third, fourth, or fifth language'. The acquisition of a second language may take place in the formal classroom setting as well as in more natural exposure situations. It is differentiated from foreign language learning in the latter refers to "the learning of a non-native language in the environment of one's native language” (Gass \& Selinker, 1994, pp. 4-5; see also Saville-Troike, 2006, p. 4).
} 
controversial issue; (c) difficulty; (d) challenge; and (e) curious phenomenon. 'Error' represents 'something wrong', and 'curious phenomenon' represents 'research question', which is near-neutral. ${ }^{3}$ Between them lie 'controversial issue', 'difficulty', and 'challenge'. Each of these meanings requires some explanation.

Before we proceed further, it should be noted in passing that in the field of ELT, teaching and learning are equally important. In fact, the present trend in education suggests moving from the teacher-centered to the learner-centered perspective (Brown, 2001), implying that learning should shape and give direction to teaching rather than the other way around (pp. 46-47). In effect, learning problems often need to be taken into account before teaching problems. Going back to the term 'error', for instance, most likely we are dealing with learning errors, and not teaching errors. Recall that 'error' lies in the extreme negative side of the semantic range presented above.

And what is error? "Errors are the flawed side of learner speech or writing" (Dulay et al., 1982, p. 138). In other words, they are target language forms produced by an L2 learner which deviate from the standard norms. Obviously, errors are learning problems, since the learner has done something wrong and needs correction. Here, errors reflect difficulty of target language learning. At the same time, however, errors are also teaching problems; they challenge the teacher with how to help the learner correct the errors. During the heyday of audiolingualism, errors had to be avoided at all costs, or else they would become part of the new language habits (Brown, 2011, p. 23). However, since the publication of Corder's (1967) "The Significance of Learners' Errors", they have been considered natural and inevitable part of FL learning. These two different opinions of errors make them a controversial issue. So errors have now come up as a curious phenomenon which needs serious investigation.

This brief discussion of errors makes it clear that errors as language problems fall within all five categories in the semantic range. Errors can be something wrong and difficulty on the part of EFL learners; they can be a challenge for EFL teachers; and they may show up as a controversial issue as well as a curious phenomenon (a research problem) for L2 researchers. The learning and teaching problems can be very complex in nature; they may interrelate, mutually influence, or affect each other.

3 The term 'near-neutral' is used to refer to 'research question', since the term 'neutral' will be used for 'topic of interest' which will be part of the discussion in the next section. 
In their discussion of errors, Dulay et al. (1982) propose two types of classifying errors: linguistic category taxonomy and surface strategy taxonomy (pp. 138-199). Under the former, errors can be grammatical or lexical errors. Under the latter, errors can be errors of omission, addition, double markings, regularization, and misformation. To illustrate, below is a sentence from a narrative written by an Indonesian high school student. ${ }^{4}$ The errors in (5) are shown by putting the words in italics.

(5) If they fallen down, certainly not save, beside the road is cliff.

To help identify the errors, a revised version of this sentence is given in

(6) If they fall down, certainly they will not be safe; on the right/left side of the road is a cliff.

By referring to (6) as the standard from, we can use the linguistic category taxonomy and identify the errors in (5): fallen is a grammatical error in verb form; save is a lexical error, a verb used in place of an adjective (safe); and beside is another lexical error, used in place of on the right/left side of. Using the surface category taxonomy, we can say that fallen is a misformation error. The intended sentence Certainly not save contains errors of omission and misformation; and the sentence beside the road is cliff contains an error of omission.

What do these errors reveal? If we take a psycholinguistic perspective and look at (5) as a partial manifestation of the learner's interlanguage (see Selinker, 1972), then we can say that those basic grammatical and lexical errors tell us that the learner (a boy) is still at the elementary level. His interlanguage or transitional competence is barely adequate for him to convey his message in good English. All of his errors are learning problems for him. For the teacher, these problems pose a challenge: how s/he should help the learner correct the errors. Obviously, the learner needs to improve his interlanguage competence; and it means that more intensive teaching is required. For L2 researchers, the errors require in-depth analysis - which reminds us of Contrastive Analysis and Error Analysis. The former explains the nature of negative transfer; the latter tells us that the errors indirectly reflect the level of the learner's transitional

\footnotetext{
4 I am grateful to Yadhi Nur Amin, M.Pd., an English teacher at MAN Lasem, Central Java, for providing me with writing data in the form of recounts written by his second-year students during the 2008/09 academic year.
} 
competence. In a nutshell, errors can be learning, teaching, and research problems.

Now I would like to move ahead and dwell on a controversial issue, a doubtful grammaticality judgment on a particular form. Overall, this derives from a personal account of teaching Advanced Applied Linguistics to doctoral students at the School of Graduate Studies (PPs), State University of Malang (UM) during the second semester of the 2011/12 academic year. One brilliant student in the class wrote an excellent essay entitled "Making their Voices Heard: Introducing the Joy of Poetry Writing through Peer Analysis". In this essay, there was a sentence containing a phrase 'quality poems' that was puzzling to me.

(7) Given sufficient exposure to quality poems, the students might in turn develop an ability to produce their own piece of poems (italics added).

In my opinion, the phrase was not grammatical. So, I corrected it, changing the phrase into "high-quality poems". The following week, the student came up to me with two sentences (written by English native speakers) containing phrases similar to hers.

Getting more bewildered, I wrote an email to four American colleaguesthree linguists (Thomas Conners, Ph.D., Thomas Hunter, Ph.D., and William O'Grady, Ph.D) and one expert in SLA (Margaret DuFon, Ph.D.).

Dear ...

I need your help as a native speaker. Last week, while correcting a paper, I read the phrase "quality poems". Then I added "high" and "a hyphen" to the phrase, making it "high-quality poems". I thought then that the phrase "quality poems" was not acceptable in English. That is, I (still) think that "quality" cannot stand as a noun modifier standing by itself.

Yesterday, the student came up with very good evidence in support of her phrase. She cited two examples from two different sources:

Another quality product from us ...

They produce quality furniture ...

Now I realize that I was wrong and she was (and is) right. I need your comments on this matter. Thank you very much for your great help. 
Best regards, Effendi

Almost immediately, I obtained three answers: from O'Grady, DuFon, and Hunter. Here is the reply from O'Grady (greeting, closing, and other personal matters omitted):

The simple answer to your question is that 'quality', used as a modifier, has come to mean 'high-quality'. We also see that even when it is used as a noun, as in 'a person/thing of quality'. Just another example of language marching on ....

DuFon gave a similar answer:

She is correct. Quality is used as a noun modifier and is in many collocations of quality + noun. I'm not sure how long we've been doing that. It might be an innovation of recent decades. I think one of the first collocations I remember was quality time, often used when speaking of the time a single father might spend with his children on week-ends (i.e., though the quantity of time was little, it was more important that that little time be quality time). Also the use of quality would entail high quality. You wouldn't use it to mean low quality. For that you'd have to actually say low quality.

Interestingly, Hunter gave a different answer (some details omitted):

In regards to using the noun quality as an adjective I'm on your side of the fence. ...

Basically I think the use of "quality" as an adjective is barbarous, and yet another sign that journalese is remaking the English language. Yes, we find "quality product" and "quality merchandise" etc. etc. but that is not the King's English. It is the language of advertising people who could care less about correct usage. ...

I would go with your side of things and prefer "high-quality" poems, which puts things into correct form, at the same time admitting to the student that there are plenty of examples out there of "quality" used as an adjective. If you are oldfashioned like me you can admit that to your student as your blood boils and 
you wish you could take an axe and go into some advertising agency somewhere and smash their furniture ...

Therefore, this is the story of 'quality poems'; it is a 'controversial issue' in prescriptive grammar, a 'difficulty' that gives a 'challenge' to me as an instructor. Two native speakers judge it correct; but one native speaker considers it wrong. Personally, I feel relieved because Dr. Thomas Hunter goes along and agrees with me. At least, my grammaticality judgment is not as bad as I thought it was. This story relates to ultimate attainment in FL learning or L2 acquisition. Saville-Troike (2006, p. 17) argues that the ultimate attainment is called 'multilingual competence', significantly different from 'native competence' as the ultimate attainment in L1 acquisition. I completely agree with this statement. Upon reflection, I am fully aware that my multilingual competence in English can never compete against my native competence in Indonesian. Whenever I am in doubt about correct grammar or usage in English, I always seek help from my native-speaker colleagues.

To sum up, EFL teaching and learning problems in Indonesian context require serious attention from applied linguists. The two illustrative examples selected in writing errors and grammaticality judgment are meant to demonstrate that naturally occurring problems (even when limited to the classroom context) can be very complex in nature, and truly challenging to ELT and AL scholars. Of course, there are dozens or even hundreds of other real teaching and learning problems which need equally serious attention and investigation, and eventually well thought-out solutions. The urgent point now is that AL should stop claiming that any language-related problem falls within its scope, and go back attending to problems in ELT and SLA.

\section{APPLIED LINGUISTICS IN INDONESIA: ELT AND SLA AS MAJOR CONCERNS}

The claim for countless and ever-growing language problems as constituting AL subject matter has been prevalent in recent textbooks: Cook's (2003) Applied Linguistics, Cook and Wei's (2009) Contemporary Applied Linguistics, Davies and Elder's (2004) The Handbook of Applied Linguistics, McCarthy's (2001) Issues in Applied Linguistics, and Spolsky and Hult's (2008) The Handbook of Educational Linguistics. Thus the claim that AL scope has been continually expanding occurs in the international sphere. Therefore, the aims of 
the critique launched in this article are twofold: first, to point out that the ambitious claim of AL in the global sphere is more pretentious than realistic; and secondly, to keep the current practice of AL in Indonesia that has remained faithful in serving the needs primarily of ELT and secondarily of SLA.

In support of the second aim, the $5^{\text {th }}$ Conference on Applied Linguistics (CONAPLIN), held at Indonesia University of Education (UPI) in September 2012, can be taken as a useful reference. The theme of the conference was "Language Teacher Development in a Globalized World"; and as noted in the leaflet and cited in Table 3, the conference covers eight areas of specialization. ${ }^{5}$

Table 3 tells us that Language Teaching, with its seven sub-topics, is the most dominant area of the conference, followed by Language Acquisition, which of course includes SLA. To keep the 'applied' nature of AL, the next two areas are Applied Psycholinguistics and Applied Sociolinguistics (italics added), suggesting that it is the application or practical sides of both disciplines that are the major concerns. Discourse Analysis and Corpus Studies constitute part of macro-linguistics, or the study of language in context, reminding us that solving a real-world language problem is always framed in a particular 'context'. As for Translation and Interpretation, applied linguists are well aware that the act of translating and interpreting always involves linguistic aspects pertaining to both the source language and the target language, telling us that this act is partly 'applications of linguistics' is the real sense of the term. Finally, Literary Studies and Social Praxis, placed at the end of the list, looks more like an addendum: who knows there are language-related problems creeping around in literature or in the society that need attention from applied linguists. $^{6}$

\footnotetext{
5 In putting the areas of coverage in Table 3, I keep the contents of CONAPLIN 5 the same as those in the original leaflet, but organize them differently for the sake of effective discussion.

6 It would be very useful if the organizing committee of CONAPLIN 5 could provide classifications of the papers presented at the conference. Just as "the International Association of Applied Linguistics Congress in 2008 had 161 papers on second language acquisition and 138 on foreign language teaching" (cited in the $2^{\text {nd }}$ section of this article), I would assume that the majority of the papers for CONAPLIN 5 were also on ELT and SLA. Hence, there were probably only few papers on the other six areas of the conference.
} 


\section{Table 3. Areas of Specialization in CONAPLIN 5}

\begin{tabular}{lll}
\hline 1. Language Teaching & 2. & First, Second and Foreign Language \\
a. Teaching Strategies and Tech- & & Acquisition \\
niques & 3. Applied Psycholinguistics \\
b. Teacher Training and Cultiva- & 4. & Applied Sociolinguistics \\
& 5. & Discourse Analysis \\
c. Trends and Challenges in Lan- & 6. & Corpus Linguistics \\
& 7. & Translation and Interpretation \\
d. Language Teaching Assessment & 8. & Literary Studies and Social Praxis \\
e. Language Teaching Policies & \\
f. Curriculum and Material Devel- & \\
opment & \\
g. Language for Specific Purposes &
\end{tabular}

This highlight on CONAPLIN 5 ties together three things. First, it is true that AL in Indonesia is primarily concerned with ELT and SLA. Secondly, there is overlap between AL and linguistics, as seen in the inclusion of (Applied) Psycholinguistics, (Applied) Sociolinguistics, Discourse Analysis, and Corpus Linguistics. They are well-known disciplines in linguistics, and are usually also included in linguistics conferences. Finally, the eight areas in CONAPLIN 5 may probably remind us of 'language problems' in AL. Definitely, these eight areas are not language problems. However, potentially there are countless topics of interest in each area, to be selected and developed into conference papers. Referring back to the five meanings of 'problem' discussed earlier (i.e., error, controversial issue, difficulty, challenge, curious phenomenon), a topic of interest sounds much like a curious phenomenon; but it is slightly different. A curious phenomenon is considered 'near-neutral', since it invites investigation; but a topic of interest invites discussion, and so it is considered 'neutral'. This is like doing a hair-splitting business; but for the purpose of achieving descriptive adequacy, the distinction is necessary.

After obtaining good support from CONAPLIN 5, I would like to find more support from the university where I teach. Now going back home and looking at the recent Catalog, English Department (2012), State University of Malang (UM), I feel relieved to find out that in the curriculum of each study program, AL goes hand in hand nicely, mostly with ELT and occasionally with SLA (noted in the course descriptions, to be discussed shortly), as shown in Table 4. 
Applied Linguistics (shown in italics in Table 4) is there in the S1, S2, and S3 curricula at the English Department at UM; it is a compulsory course only in the S2 curriculum, but an elective course in both S1 and S3 curricula. In both curricula of the two S1 programs the official name of the course is 'Applied Linguistics', in the S2 curriculum 'Critical Review on Applied Linguistics', and in the S3 curriculum 'Advanced Applied Linguistics'. In the study programs of all levels, Applied Linguistics goes together with TEFL and SLAwith varied names for the last two courses.

Notice that the official name for the S1, S2, and S3 study programs is ELT (English Language Teaching), with the S1 study program in English Language and Literature being a different program. Interestingly, all the three courses (AL, TEFL, and SLA) are offered in the study programs of all levels, including the S1 program in English Language and Literature, albeit as elective courses. When students at this S1 study program graduate and want to teach English, the Department has already provided them with some theoretical knowledge and practical skill of how to teach English as a foreign language.

Table 4. Applied Linguistics, TEFL, and SLA in the S1, S2, and S3 Curricula (cited partially) of English Department UM

\begin{tabular}{|c|c|c|c|c|}
\hline No. & $\begin{array}{l}\text { Study Pro- } \\
\text { gram }\end{array}$ & Course & $\begin{array}{l}\text { Credit } \\
\text { Hours }\end{array}$ & Offering Status \\
\hline \multirow{3}{*}{1} & \multirow{3}{*}{$\mathrm{S} 1 \mathrm{in} \mathrm{ELT}$} & Applied Linguistics & 2 & elective \\
\hline & & TEFL & 4 & compulsory \\
\hline & & Second Language Acquisition & 2 & elective \\
\hline \multirow{3}{*}{2} & \multirow{3}{*}{$\begin{array}{l}\text { S1 in English } \\
\text { Language \& } \\
\text { Literature }\end{array}$} & Applied Linguistics & 2 & elective \\
\hline & & TEFL & 2 & elective \\
\hline & & Second Language Acquisition & 2 & elective \\
\hline \multirow{3}{*}{3} & \multirow{3}{*}{ S2 in ELT } & $\begin{array}{l}\text { Critical Review on Applied } \\
\text { Linguistics }\end{array}$ & 2 & compulsory \\
\hline & & Methods of TEFL & 2 & compulsory \\
\hline & & $\begin{array}{l}\text { Critical Review on SLA Re- } \\
\text { search }\end{array}$ & 2 & compulsory \\
\hline
\end{tabular}

7 The S1, S2, and S3 curricula of the English Department at UM are partially cited here as an example needed for analysis. S1 curricula of English Departments throughout Indonesia may probably be different from one another. However, I would assume that the curriculum of every S1 study program in ELT contains the three courses: Applied Linguistics, TEFL, and SLA-with TEFL being the most important. Of course, a survey is needed to verify whether or not my assumption is right. 


\begin{tabular}{llllll}
\hline No. & $\begin{array}{c}\text { Study } \\
\text { gram }\end{array}$ & Pro- & Course & $\begin{array}{l}\text { Credit } \\
\text { Hours }\end{array}$ & Offering Status \\
\hline \multirow{3}{*}{4} & \multirow{3}{*}{ S3 in ELT } & Advanced Applied Linguistics & 3 & elective \\
\cline { 3 - 5 } & & Topics in ELT & 2 & compulsory \\
\cline { 3 - 5 } & & Research in SL Reading & 2 & elective \\
\cline { 3 - 5 } & Research in SL Writing & 2 & elective \\
\hline
\end{tabular}

Of greater importance are course descriptions for $\mathrm{AL}$ offered at the three levels (S1, S2, and S3) of the programs (only relevant parts of the course descriptions contained in the Catalogue are cited here, mostly through paraphrases). For both S1 study programs (p. 42), AL provides students with adequate knowledge of the relationship between research findings in linguistics and English language teaching and learning. Obviously, this is practicing AL of the old paradigm.

For the S2 study program (p. 55), AL is also concerned with the application of linguistic principles in FL teaching and learning, but the contents of the course include, among others, reorientation and redefinition of $\mathrm{AL}$ as a problem-driven discipline. Here we see that AL has moved one step ahead toward autonomy, although still showing strong dependence on theoretical linguistics.

For the S3 study program (p. 60), AL seeks to point out how linguistic theories influence and give shape to TEFL and SLA. Reorientation of AL is explicitly mentioned, from a theory-affiliated discipline to a problem-driven discipline. Moreover, the major concern is to keep its primary goal: bridging the gap between theoretical linguistics and TEFL as well as SLA. Here we see that AL has become more autonomous, while keeping harmonious relationship with linguistics.

The discussion of the three course descriptions for $\mathrm{AL}^{8}$ boils down to three major points. First, in the study programs of all levels, AL has been designed to serve the needs of TEFL/ELT and to some extent SLA, suggesting that AL at the English Department at UM has been in the right direction. Secondly, as it redefines itself, AL has gained more freedom and become a problem-driven discipline (italics added). It is the term "problem" here that has led (or misled)

\footnotetext{
8 The aims and contents of LA course descriptions for the S1, S2, and S3 ELT study programs here can be typical of English Department at UM. LA course descriptions in other English Departments in Indonesia may have different aims and contents. Again, the analysis is given here simply as 'one illustrative example' of what AL looks like in the Indonesian ELT context.
} 
the discipline to claim that any language-related problem falls within the scope of AL. All the arguments presented earlier should be more than adequate in proving the falsity of the claim. Third and last, it is interesting to observe that $\mathrm{AL}$ - as going up through the S1, S2, and S3 course descriptions-seems to have been moving on toward much greater autonomy. Now, a crucial question arises. How much autonomy does AL need? This question needs long answers; and they will be given in the following section.

Upon reflection, referring to CONAPLIN 5 and the curricula of S1, S2, and S3 study programs in ELT at the English Department at UM, it is true that AL in Indonesia has been on the right track; it has been in good service to ELT and SLA. There is no need for AL in Indonesia to grab every language-related problem and make it part of its subject matter. Within ELT and SLA alone, there are innumerable problems waiting for AL to attend to. Recall that 'language problem' has a huge range of meanings: error, controversial issue, difficulty, challenge, curious phenomenon, and topic of interest. Accordingly, AL in Indonesia may make considerable progress by focusing on naturally occurring problems in ELT and SLA, which may become more abundant owing to the possibility that each problem may get multiplied by more than one interpretation.

\section{QUESTION OF AUTONOMY IN APPLIED LINGUISTICS (AND ELT IN INDONESIA)}

Let us go back to the question: how much autonomy does AL need? Or, in other words, how does AL relate to theoretical linguistics? This question has brought up different answers, settling down eventually to three types of relationship: minimum dependence on linguistics, mutual need between AL and linguistics, and (moderate or strong) reliance on linguistics.

The first position is stated clearly by Cook and Wei (2009), "Linguistics nowadays plays a minimum role in applied linguistics" (p. 2). In fact, linguistics is only one of the contributing disciplines. They further point out that "ap-

plied linguists have explored psychological models such as declarative/procedural memory and emergentism, mathematical models such as dynamic systems theory or chaos theory, early Soviet theories of child development such as Vygotsky, French thinkers such as Foucault and Bourdieunothing seems excluded" (Cook \& Wei, 2009, p. 2). It seems that they have some feeling of dislike toward linguistics; and it turns out to be true. According 
to Cook and Wei (2009), "indeed some practitioners radiate hostility toward linguistics, preferring to draw on almost any other area" (p. 3). These scholars have unintentionally dispelled the word 'linguistics' from 'applied linguistics', hence making the discipline in limbo. Most probably, this first position is the position of AL that takes every language-related problem into the confines of its subject matter; and this is a favorable position for the Jack of all trades applied linguists.

The second position is best represented by McCarthy (2001, p. 4-5), following earlier steps taken by Widdowson $(1980,1984)$. McCarthy argues that $\mathrm{AL}$ as a problem-driven discipline relates to 'linguistics as a partner', not a mother discipline. Scholars of both disciplines have different responsibilities. The responsibility of linguists is to build theories of language that are verifiable, and to offer models, descriptions, and explanations of language that satisfy not only intellectual rigor but intuition, rationality, and common sense. On the other hand, the responsibility of applied linguists is not simply to 'apply linguistics' but - by looking critically at theories, models, and descriptions of language - to work toward 'relevant models' of their own that best suit the purpose of solving language problems at hand. "The applied linguist is a gobetween", noted Cook and Wei $(2009$, p. 3), whose primary task is "provide an interface between linguists and practitioners where appropriate, and to be able to talk on equal terms to both parties" (McCarthy 2001, p. 5). Although sharing different intellectual responsibilities, McCarthy continues, scholars of both disciplines "should adopt a critical position vis-à-vis the work of their peers, both within and across the two communities" (p. 5). Partnership and equal footing between both disciplines as suggested by McCarthy could be an ideal relationship; but the bare facts should not be overlooked: "theories, models, and descriptions of language" precede 'relevant models' designed by applied linguists. This suggests that, so long as AL derives its own models either directly or indirectly from research findings in linguistics, the claim for the equal footing remains an aspiring ideal rather than an accomplished fact.

The strong reliance on linguistics is proposed by The International Association of Applied Linguistics (AILA 2009), which proclaims that "applied linguistics is an interdisciplinary field of research and practice dealing with practical problems of language and communication that can be identified, analysed or solved by applying available theories, methods or results of Linguistics or by developing new theoretical and methodological frameworks in Linguistics to work on these problems" (Cook \& Wei, 2009, p. 1). In this definition, AL 
looks like a daughter discipline, whose job is to solve language problems by applying linguistics or inventing a linguistics-based framework. This position of strong dependence is probably rejected by most present-day applied linguists.

On the other hand, the moderate reliance on linguistics can be seen in the work of Cook (2003), who defines AL as "the academic discipline concerned with the relation of knowledge about language to decision making in the real world" (p. 5). He states that at present there is a difficult relationship between $\mathrm{AL}$ and linguistics. Both context-free linguistics (best represented by generative linguistics) and context-bound linguistics (as represented particularly by sociolinguistics, functional linguistics, and discourse analysis) have moved along at the conceptual level: trying to describe and explain, and eventually build a theory or draw general principles of language. This is of course so far apart from the AL decision-making business in dealing with real-world language problems (Cook, 2003, pp. 9-10).

And yet, despite the different goals of both disciplines, Cook still believes in the significant role of linguistics. He states that LA methodology is by necessity complex; "it must refer to the findings and theories of linguistics, choosing among different schools and approaches, and making these theories relevant to the problem at hand" (Cook, 2003, p. 10). On the one hand, this scheme is very similar to what Widdowson (1984) calls 'relevant models', which take into account not only linguistic descriptions but also native speakers' intuition. On the other hand, the scheme is in accord with McCarthy's (2001) proposal for "theoretical stance" without making "theoretical allegiance" (pp. 5-7). Theoretical stance means that AL should build its own "theory' or systematic way of approaching L2 learning and teaching problems, whereas theoretical allegiance refers to choosing one particular linguistic theory with the belief that it is the 'best theory' for FL teaching.

In the past, theoretical allegiance showed up in the global sphere (with its massive influence in Indonesia during the 1970s and early 1980s) in the adoption of Bloomfieldian linguistics together with behaviorist psychology as foundations for the Audiolingual Method. Then, scholars came to realize that L2 acquisition is a lot more than habit formation through drilling; for L2 in the making is in fact an independent and dynamic language system of its own, called 'interlanguage' (Selinker, 1972) or 'transitional competence' (Corder, 1967). Notice that the term 'competence' here originates from Chomsky (1965, p. 4), carrying with it a strong flavor of mentalism that is in total opposition to 
behaviorism. And mentalism has indeed succeeded in its attack on behaviorism, and pushing it off the stage.

Criticizing behaviorism and audiolingualism today is like killing a dead horse; but from this lesson a relevant question arises: does 'theoretical allegiance' that has failed with audiolingualism take place today? Strangely enough, it does; and it does occur in Indonesia. The 2004 curriculum for Indonesian high schools, under the big umbrella of communicative language teaching (CLT), has adopted the so-called systemic functional linguistics genrebased approach (SFL GBA), which relies heavily on Hallidayan linguistics. With audiolingualism, the prominent activity was drilling; with the GSA, the center of ELT is genre or text. But there is an important difference. The Audiolingual Method was so well outlined and straightforward that EFL teachers knew exactly what they were required to do. By contrast, the GBA, which seems to require the teachers to understand Hallidayan basic linguistic principles before doing the teaching, has caused much confusion. ${ }^{9}$ Emilia's (2011) book, Pendekatan Genre-Based dalam Pengajaran Bahasa Inggris: Petunjuk untuk Guru (Genre-Based Approach in English Language Teaching: A Guide for the Teachers) is an excellent helping hand, which has done its best to sweep out the confusion and try to put the teachers back in confidence. But this generous intellectual help does not negate the fact that ELT in Indonesia has been trapped by the strong belief that a particular linguistic school can offer a 'best approach'. Moreover, AL and SLA were not there yet during the formation of audiolingualism; but in the first decade of the $21^{\text {st }}$ century, when the GBA was adopted in Indonesia, all insights from highly well-developed AL, SLA, and TEFL were there at our disposal, but seemed to have been ignored.

So, the question of autonomy now turns from LA to ELT: how much autonomy does ELT in Indonesia need? It does not need autonomy. Just as audiolingualism was happy thriving under the domination of Bloomfieldian linguistics, the GBA is equally happy struggling under the shadow of Hallidayan lin-

\footnotetext{
9 The confusion among Indonesian EFL teachers is clearly stated by Professor Fuad Abdul Hamied, Ph.D., current TEFLIN President, in his preface to Emi Emilia, Ph.D.'s book (p. iii). "Berkenaan dengan SFL GBA, TEFLIN mengamati adanya kebingungan, kesalahpahaman di kalangan para guru, baik berkenaan dengan prinsip dasar maupun aplikasinya di kelas yang mengakibatkan terjadinya 'malpraktek' dari pendekatan itu" [With regard to the SFL GBA, TEFLIN observes that there has been confusion or misunderstanding among teachers, concerning either its basic principles or its application in the classroom, which results in the "malpractice" of the approach.]
} 
guistics. This GBA incidence makes the question of autonomy in ELT in Indonesia somewhat irrelevant. Some autonomy is there for EFL teachers to plan and implement the teaching-learning process; but the freedom is within the confines of Hallidayan linguistics. In other words, the practice of ELT in Indonesia is still much under the cast of linguistic shadow. Will the newly introduced 2013 curriculum change the present state of ELT Indonesia? We are all in the position of 'wait and see'.

From the off-side notes on ELT in Indonesia, let us go back to the question of autonomy in AL. While AL scholars have been so busy defining the position of $\mathrm{AL}$ vis-à-vis linguistics, theoretical linguists, to the best of my knowledge, are never aware of this AL hectic business. What they know is that $\mathrm{AL}$ is there as a sub-field of linguistics, just as other subfields (such as psycholinguistics, neurolinguistics, and forensic linguistics) are there making up linguistics a much richer, constantly growing discipline.

In fact, the tension or sometimes hostility has been there in linguistics between scholars of different schools or persuasions. During the 1960s there was a devastating attack by generative linguists on the Bloomfieldian school, claiming that it lacked descriptive and explanatory adequacy (Chomsky, 1965, pp. 48). Then there were 'linguistics wars' (Harris, 1995) between Chomsky and his former students, founders of generative semantics. For Chomsky, the most prominent part of linguistic theory was (and still is) syntax; but for his students it was semantics. The wars lasted for about a decade, with Chomsky coming out victorious. Next, sociolinguists such as Hudson (1970) and Hymes (1972, 1974) launched serious criticism of Chomsky for ignoring language use in social context; but, since Chomsky believes that language is a mental, not a social fact, he never gives any response to them. Another cause of resentment against Chomsky comes from proponents of linguistic relativity (see, e.g., Gumperz \& Levinson, 1996) and linguistic particularity (Becker, 1995), especially for his insistence on linguistic universality, culminating in the theory of Universal Grammar (UG) which is so abstract in nature and detached away from actual language use (Chomsky, 1981, 1995). This list may go on and on; but it should stop at this point. At this point, it is Chomsky who has been at the center of linguistic turbulence for nearly four decades, and has remained a legend-adored as an angel, but also loathed as a devil (Harris, 1995, p. 77).

At this point, applied linguists should be well aware that their hectic business of defining AL position has no effect whatsoever on linguistics. In fact, the negative effect fires back on itself. A number of books bearing the name 
Applied Linguistics can be difficult or very difficult for (prospective) EFL teachers to read. This is because, in discussing the position of AL, the authors assume that the readers have adequate knowledge about linguistic aspects they criticize. To illustrate, going back to Widdowson's (1984, p. 14) attack on Chomsky's example "Flying planes can be dangerous" discussed earlier in this article, I have found out that none of my EFL students, even at the doctoral level, understands the point Widdowson has eloquently made. Obviously, they lack syntactic knowledge on which Chomsky builds his argument for the necessity of the deep structure underlying the ambiguity of the sentence.

Another example is McCarthy's (2001) furious attack on 'sentence grammar', preferring implicitly to teach 'discourse grammar' (pp. 50-53). Putting a provocative sub-heading "Sentence: Friend or Foe", McCarthy argues along the way pointing out that sentences as linguistic units are inadequate for expressing speaker meanings in actual verbal communication. He sums up his argument, saying, "In language pedagogy, the sentence may be less than useful, even irrelevant, in performing mundane speech acts such as greetings, suggestions, thanks, and apologies, not to mention in the extended performance of spoken collaborative tasks" (McCarthy, 2001, p. 53). Briefly, for McCarthy the sentence is the enemy. This provocative argument must be confusing to EFL teachers; for when they teach grammar in their daily routines, they teach sentence grammar.

What is wrong with sentence grammar? Upon careful examination, what McCarthy says is nothing but an echo of arguments in pragmatics and sociolinguistics. Referring to pragmatics, he gives prominence to speaker meaning (illocutionary force) rather than sentence meaning (locutionary force). Referring to sociolinguistics, he believes more in communicative competence proposed by Hymes (1972) rather than in linguistic competence proposed by Chomsky (1965). When applied linguists have strong passion to carry over controversial issues in linguistics into $\mathrm{AL}$, the result is confusion on the part of the practitioners.

To conclude this section, the real issue is not how much autonomy AL needs, but rather, how well the applied linguist understands linguistic theories, methods, and descriptions; and how well they are able to make the best use of these findings for the purpose of solving the problem at hand. Recall that a problem may have a huge range of meanings; and understanding the nature of a given problem will help provide the best possible solution. From my own experience of learning the two disciplines, as my knowledge of linguistics develops, 
my understanding of AL and its directions goes deeper and becomes better. At the same time, from the personal experience of teaching AL through the years and looking carefully at its controversial issues, I have come to realize why parts of pure linguistics incite disappointment, frustration, or even resentment on the part of the applied linguists. Overall, the term 'linguistics' in 'applied linguistics' can be either a curse or a blessing, depending on how applied linguists relate the two disciplines.

The shift of paradigm from LA to AL is a historical construct invented by the 'good guys'. It is useful as an academic discourse, but of little value when AL has to come down to the actual problem-solving business. The claim for the ever-expanding scope of AL gives more disadvantage than advantage, since the discipline will fail to produce real professionals and produce only Jack of all trades applied linguists. So, going back to the essentials is necessary: focusing on real language problems in ELT and SLA.

In this respect, AL in Indonesia has all along been on the right tract, without neglecting the necessary exposure to the international sphere to keep itself well-informed. CONAPLIN at UPI has set up a good example of doing AL in the country. It focuses on language problems in ELT and SLA, while allowing other closely related disciplines to offer topics of interest to enrich the scholarly discussion. Looking at the seven sub-disciplines of ELT at the $5^{\text {th }}$ CONAPLIN (i.e., (a) teaching strategies and techniques; (b) teacher training and cultivation; (c) trends and challenges in language teaching; (d) language teaching assessment; (e) language teaching policies, (f) curriculum and material development; and (g) language for specific purposes), the real need becomes clear-not the specific knowledge of linguistics, but the broad knowledge of language and other relevant disciplines.

The 'quality poems' example presented in the third section of this article is meant to tell the reader that there is nothing trivial in scholarship. Only by treating a minor problem in a serious manner can we solve bigger problems satisfactorily. Similarly, I am fully aware that both side-track notes in the last section may weaken the coherence of the essay. But their significant value is more important than the rhetorical structure of the essay. The adoption of the genrebased approach that bewilders Indonesian EFL teachers is deplorable, because it shows that the practice of AL in Indonesia has at one time stumbled on the stone of ignorance. From the heated debates among theoretical linguists arguing for the 'best theory', applied linguists should learn a good lesson. Now there is no need to define AL position against linguistics, since it has turned out 
to be an energy-consuming, time-wasting, and fruitless attempt. In fact, it has backfired and made some AL books and reading materials less accessible to (prospective) EFL teachers.

The right way of doing AL expectedly yields a systematic attempt to correct learning errors, settle controversial issues, face challenges, overcome difficulties, conduct research on curious phenomena, select and discuss topics of interest, and make right decisions on issues concerning ELT and SLA problems. By doing so, AL has clearly defined itself as a problem-driven discipline, not a problem-inciting discipline. Keeping and blowing up trivial issues on its relationship with linguistics would not make AL gain better academic standing, but would make it part of annoying language problems!

\section{Acknowledgements}

I would like to thank, first, Nurenzia Yannuar, an M.A. degree holder in Linguistics and a colleague at the English Department, State University of Malang, for proofreading and suggesting improvements of the earlier draft, and, secondly, an anonymous reviewer for suggesting important revisions and correcting errors of the submitted manuscript. Any possible shortcomings and deficiency, however, are my responsibility alone.

\section{REFERENCES}

Allen, H. B. (1964). Readings in applied English linguistics. New York: Appleton-Century-Croft.

Becker, A. L. (1995). Beyond translation: Essays toward a modern philology. Ann Arbor: The University of Michigan Press.

Bloomfield, L. (1933). Language. Chicago/London: The University of Chicago Press.

Brown, D. H. (2001). Teaching by principles: An interactive approach to language pedagogy (Second Edition). New Jersey: Prentice Hall Regents.

Brumfit, C. C. (1991). Applied linguistics in higher education: Riding the storm. BAAL Newsletter, 38, 45-9. 
Catalog, English Department (2011). Malang: Faculty of Letters, State University of Malang.

Chomsky, N. (1957). Syntactic structures. The Hague: Mouton.

Chomsky, N. (1965). Aspects of the theory of syntax. Cambridge, Massachusetts: The MIT Press.

Chomsky, N. (1981). Lectures on government and binding. Mouton: The Gruyter.

Chomsky, N. (1995). The minimalist program. Cambridge, Massachusetts: The MIT Press.

Cook, G. (2003). Applied linguistics. Oxford: Oxford University Press.

Cook, V., \& Wei, L. (2009). Applying linguistics and language teaching in the twenty-first century. In V. Cook \& L. Wei (Eds.), Contemporary Applied Linguistics: Language Teaching and Learning (Vol 1), (pp. 1-9). New York: Continuum.

Corder, S. P. (1967). The significance of learner's errors. In J. C. Richards. (Ed.), Error analysis: Perspectives on second language acquisition (pp. 19-30). London: Longman.

Davies, A. (2004). Introduction to part I: Linguistics applied (L-A). In A. Davies \& C. Elder (Eds.), The handbook of applied linguistics (pp. 19-24). Malden, MA: Blackwell Publishing.

Davies, A., \& Elder, C. (2004). General introduction, applied linguistics: Subject to discipline? In A. Davies \& C. Elder (Eds.). The handbook of applied linguistics (pp. 1-15). Malden, MA: Blackwell Publishing.

Dulay, H., Burt, M., \& Krashen, S. (1982). Language two. Oxford: Oxford University Press.

Emilia, E. 2011. Pendekatan genre-based dalam pengajaran bahasa Inggris: Petunjuk untuk guru [Genre-based approaches in English teaching: Guidelines for teachers]. Bandung: Rizqi Press.

English 900: A basic course (volumes 1, 2, 3, 4, 5, 6). (1964). New York: Collier Macmillan International, Inc. 
English for the SLTA series: Students' book I, II, III, and supplementary reader I, II, III. (1981). Jakarta: Balai Pustaka.

Fries, C. C. (1945). Teaching and learning English as a foreign language. Ann Arbor: The University of Michigan Press.

Gass, S. M., \& Selinker, L. (1994). Second language acquisition: An introductory course. Hillsdale, New Jersey: Laurence Erlbaum Associates, Publishers.

Gumperz, J. J., \& Levinson, S. C. (1996). Rethinking linguistic relativity. Cambridge: Cambridge University Press.

Harris, R. A. (1995). The linguistics war. New York/Oxford: Oxford University Press.

Hudson, R. A. (1970). Sociolinguistics. Cambridge: Cambridge University Press.

Hult, F. M. (2008). The history of educational linguistics. In B. Spolsky \& F. M. Hult (Eds.), The handbook of educational linguistics (pp. 10-24). Malden, MA: Blackwell Publishing.

Hymes, D. (1972). On communicative competence. In J. B. Prides \& J. Holmes (Eds.), Sociolinguistics (pp. 269-85). Harmondsworth: Penguin.

Hymes, D. (1974). Foundations in sociolinguistics: An ethnographic approach. Philadelphia: University of Pennsylvania Press.

Lado, R. (1964). Language teaching: A scientific approach. New York: McGraw-Hill, Inc.

McCarthy, M. (2001). Issues in applied linguistics. Cambridge: Cambridge University Press.

Rajagopalan, K. (2004). The philosophy of applied linguistics. In A. Davies \& C. Elder (Eds.), The handbook of applied linguistics (pp. 397-420). Malden, MA: Blackwell Publishing.

Saville-Troike, M. (2006). Introducing second language acquisition. Cambridge: Cambridge University Press. 
Selinker, L. (1972). Interlanguage. In J. C. Richards (Ed.), Error analysis: Perspectives on second language acquisition (pp. 31-54). London: Longman.

Spolsky, B. (2008). Introduction: What is educational linguistics? In B. Spolsky \& F. M. Hult (Eds.), The handbook of educational linguistics (pp. 19). Malden, MA: Blackwell Publishing.

Widdowson, H. G. (1980). Models and fictions, Applied Linguistics 1(2), 16570.

Widdowson, H. G. (1984). Applied linguistics: The pursuit of relevance. In H. G. Widdowson (Ed.), Explorations in applied linguistics, 2 (pp. 7-20). Oxford: Oxford University Press.

Widdowson, H. G. (2000). On the limitations of linguistics applied. Applied Linguistics, 21(1), 3-25. 